\title{
DETERMINING THE SCOPE OF CHOICE OF LAW PROVISIONS IN STEAMSHIP TICKETS: ADHESION CONTRACTS AND THE CONFLICT OF LAWS*
}

IN nearly all jurisdictions parties to a contract may stipulate the law by which their agreement is to be governed. ${ }^{1}$ The only limitations placed by courts on the parties' autonomy in choice of law are that the chosen law be related to the transaction, ${ }^{2}$ that the reason for adopting it be bona fide, ${ }^{3}$ and that the results reached by use of the chosen law not violate the public policy of the forum. ${ }^{4}$ But while it is usually clear that parties may stipulate the use of the law of a foreign country, it is sometimes not clear to what extent such a provision should govern subsequent dealings between the parties relating to the contract. A recent case raises this problem, and presents the further question of whether such a stipulation and other contractual provisions contained in steamship tickets should be afforded special treatment because these tickets are adhesion contracts. ${ }^{5}$

*Siegelman v. Cunard White Star Ltd., 221 F.2d 189 (2d Cir. 1955).

1. Mutual Life Ins. Co. v. Hill, 193 U.S. 551 (1904); Ehrenzweig, Adhesion Contracts in the Conflict of Lazes, 53 Colum. L. Rev. 1072, 1073-74 (1953); Yntema, Contract and Confict of Lazus: "Autonomy" in Choice of Law in the United States, 1 N.Y.L. FORUM 46 (1955). But cf. Restatedrent, Conflict of Laws $\$ 332$ (1934) which provides only that the validity of a contract be determined by the lex loci contractus.

2. Seeman v. Philadelphia Warehouse Co., 274 U.S. 403 (1927) ("normal relation"); Hal Roach Studios, Inc. v. Film Classics, Inc., 156 F.2d 596 (2d Cir. 1946) ("reasonable relationship"); Owens v. Hagenbeck-Wallace Shows Co., 58 R.I. 162, 192 At1. 158 (1937) ("real relation"). But see Duskin v. Pennsylvania-Central Airlines Corp., 167 F.2d 727 (6th Cir.), cert. denied, 335 U.S. 829 (194S) (no limitation but "public policy").

3. Seeman v. Philadelphia Warehouse, supra note 2; Albritton v. General Finance Corp., 204 F.2d 125 (5th Cir. 1953) ; Yntema, Autonomy in Choice of Law, 1 Anr. J. CoMr. L. 341, 354 (1952). The requirement of bona fides appears, however, to be met when the stipulated law bears a reasonable relationship to the transaction. See Seeman v. Philadelphia Warehouse Co., supra.

4. Duskin v. Pennsylvania-Central Airlines Corp., 167 F.2d 727 (6th Cir.), cert. dcricd, 335 U.S. 829 (1948); 2 Beale, Conflict of Laws 1116 (1935).

Exculpatory clauses reducing a vessel's liability for negligence to passengers are void as against public policy, 49 STAT. 1480 (1936), 46 U.S.C. $\$ 183$ (c) (1952), even though valid by the law stipulated in the contract. The Kensington, 183 U.S. 263 (1902); Oceanic Steam Nav. Co. v. Corcoran, 9 F.2d 724 (2d Cir. 1925).

A carrier may limit its liability for damage to baggage only if it provides the passenger with an option to insure the full value of the baggage. See Bachman v. Clyde S.S. Co., 152 Fed. 403 (2d Cir. 1907) ; Cohn v. United States Lines Co., 84 F. Supp. 503 (D.N.J. 1949); Reichman v. Compagnie Generale Transatlantique, 290 N.Y. 344,49 N.E.2d 474 (1943). For discussion of option and consideration as grounds for the carrier's selfexculpation from tort liability, see Note, 37 CoLun. L. Rev. 248, 250-55 (1937).

5. See notes $23-48$ infra and accompanying text. See also Ehrenzweig, supra note 1, at 1075 . 
In Siegelman v. Cunard White Star Ltd., ${ }^{6}$ a passenger sued the steamship company for damages resulting from a personal injury sustained aboard the Queen Elizabeth during a trip from New York to Cherbourg. In a conversation with Siegelman's attorney eleven months after the accident, Cunard's New York claim agent offered $\$ 800$ in settlement of the passenger's claim. The attorney agreed to inform his client of the offer, but indicated that he would also institute suit against Cunard to prevent the bar of a one year limitation of actions provision in the ticket. ${ }^{7}$ The agent replied that the prospect of early agreement made filing a complaint unnecessary. No complaint was filed and no settlement was reached before the one year period expired. Three months after it ended, Cunard's offer was revoked. Eleven months later plaintiff brought his action which was dismissed in the lower court for the reason that the one year limitation period had run and that the agent had no authority to waive the provision. ${ }^{8}$

The Second Circuit affirmed the dismissal, but on the grounds that a second ticket provision stipulating that English law was to govern "all matters arising on the contract" applied to the issue of waiver, ${ }^{9}$ and that under English law defendant's agent had not waived the limitation provision. ${ }^{10}$ The court con-

6. 221 F.2d 189 (2d Cir. 1955).

7. Provision 10 of the ticket reads in part:

"No suit, action or proceeding against the Company or the ship, or the Agent" of either, shall be maintainable for loss of life of or bodily injury to any passenger unless ... (b) .... the suit, action or proceeding is commenced within one year from the day when the death or injury occurred."

Siegelman v. Cunard White Star Ltd., 221 F.2d 189, 209 (2d Cir. 1955). By federal statute the minimum permissible limitation period for such actions is one year. 49 STAr. 960 (1935), 46 U.S.C. $\$ 183$ (b) (1952).

8. Siegelman v. Cunard White Star Ltd., 221 F.2d 189, 197 (2d Cir. 1955). The lower court relied on provision 11 of the ticket which reads in part:

"[N]o agreement, alteration or amendment creating any other or different liability shall be valid unless made in writing and signed for the Company by its Chief Agent at the port of embarkation."

Id. at 209.

9. Provision 20 of the ticket reads:

"All questions arising on this contract ticket shall be decided according to English Law with reference to which this contract is made."

Ibid.

10. Id. at 198 .

English law had been neither pleaded nor proved in the district court below. Id. at 196 . But the Second Circuit ruled that under FED. R. Crv. P. 8(a) foreign law need not be pleaded. Then, by combining N.Y. Crv. PRAC. ACT \& 344-a (New York courts may take judicial notice of the unproved law of a foreign country) and Fed. R. Crv. P. 43(a) (federal courts use state rather than federal admissibility rules if more favorable to the reception of evidence), the court held that the unproved foreign law could be applied. Siegelman v. Cunard White Star Ltd., 221 F.2d 189, 196-97 (2d Cir. 1955).

Both before and since adoption of the present Federal Rules of Civil Procedure, federal courts, in the absence of state statutes allowing judicial notice of the law of a foreign 
sidered it desirable to apply English law to the contract in order to honor the parties' intent, and because choice of law provisions aid courts in settling conflict of laws questions and lead to uniform results in litigation. The court concluded that since the parties intended that English law should govern the validity and interpretation of the contract, it would be "unnatural" to assume that they did not intend the same law to control the issue of waiver. 11 Because, under the court's interpretation of English law, the agent's conversation with plaintiff's attorney did not constitute waiver of the limitation provision, the suit was dismissed.12 Judge Frank, dissenting, reasoned that, inter alia, steamship tickets are contracts of adhesion and therefore should be strictly construed against the drafter. Since there was doubt about whether the English law provision applied to waiver, and since the federal law of waiver was more favorable to the passenger than that of England, he would have applied federal law. ${ }^{13}$

country, have refused to apply such law unless pleaded and proved. E.g., Bonsalem v. Byron S.S. Co., 50 F.2d 114 (2d Cir. 1931) ; Harris v. American Int'l Fuel and Petroleum Co., 124 F. Supp. 878 (W.D. Pa. 1954). Prior to the Siegelman case, only two federal courts had spoken on this issue where a state statute provided for judicial notice of the law of a foreign country. In Empresa Agricola Chicama Ltda. v. Amtorg Trading Corp., 57 F. Supp. 649 (S.D.N.Y. 1944), the court ruled that FED. R. CIv. P. 43 (a) and N.Y. CIv. Prac. ACT $\$ 344-a$ dispensed with the necessity of proving foreign law, but not with the need for pleading it. But in Jansson v. Swedish American Line, 89 F. Supp. 557 (D. Mass.), rov'd on other grounds, 185 F.2d 212 (1st Cir. 1950) the court stated by way of dictum that under FED. R. Cw. P. 43(2) the foreign law need not be pleaded.

Seven states now have statutes allowing judicial notice of the law of a foreign country. McCormick, Iudicial Notice, 5 VAnd. L. Rev. 296, 307 (1952). If Siegelman is followed, foreign law need not be pleaded in any federal court, but it must be proved in all but these seven states. If the parties are given reasonable notice that a foreign law is to be applied, there scems to be no valid justification for pleading and proving such law. See Keeffe, Landis \& Shaad, Sense and Nonsense about Indicial Notice, 2 STAN. L. Rev. 664, 688-90 (1950).

11. Siegdman v. Cunard White Star Ltd., 221 F.2d 189, 194 (2d Cir. 1955).

12. Id. at 198. The court relied on a rule of law formerly accepted by English courts that representation of an intent to abandon a legal right will not create estoppel. Provident Acc. \& White Cross Ins. Co. v. Dahne, [1937] 2 A11 E.R. 255 (K.B.) ; Jorden v. Money, 5 H.L. 185, 10 Eng. Rep. \&6S (1854); see Bank of Baroda, Ltd. v. Punjab Nat'l Bank, Ltd., [1944] A.C. 176 (P.C.). More recent cases, however, have held that an assurance or promise intended to affect legal relations between parties and intended to be acted upon becomes binding when the other party has acted in reliance. Robertson v. Minister of Pensions, [1949] 1 K.B. 227 (1948) ; Ledingham v. Bermejo Estancia Co., [1947] 1 All E.R. 749 (K.B.) ; Central London Property Trust Ltd. v. High Trees House Ltd., [1947] 1 K.B. 130, 134 (1946) ("The law has not been standing still since Jorden v. Money. ..."); see Note, G3 L.Q. REv. 2\$3, 300 (1947), commenting on and approving the newer English view.

But such an assurance or promise is binding only so far as its terms properly apply. Ledingham v. Bermejo Estancia Co., supra; Central London Property Trust Ltd. v. High Trees House Ltd., supra. In the instant case, the assurance, being based on the excellent chance for settlement, would probably cease to be binding within a reasonable time after revocation of the settlement offer. Therefore plaintiff's suit, which was not commenced uritil eleven months later, would probably still be barred by the limitation of actions clause.

13. Sicgelman v. Cunard White Star Ltd., 221 F.2d 189, 199 (2d Cir. 1955). But 
Even though English contract law was binding on the plaintiff, the majority's application of English law to the issue of waiver is contrary to the usual holding that parties do not intend foreign law provisions to extend to procedural matters. ${ }^{14}$ Statutes of limitation concerning common law actions are procedural and are governed by the lex for $i^{15}$ And both contractual and non-contractual exceptions to the bar of such statutes are governed by the lex fori on the

adhesion contract principles should not demand that the adherer win in every case. They only require courts to overcome particular characteristics which prevent freedom of contract. See text at notes $23-48$ infra.

In addition to his adhesion contract argument, Judge Frank would reverse for several other reasons: (1) English law as interpreted by the majority is against American public policy; (2) the RESTATEAIENT, CONFLICT OF LAwS $\$ 373$ (1934) shows persuasively that American law should govern waiver; (3) English conflict of laws principles should be applied, and these might permit consideration of American law of waiver; and (4) the case cited by the majority opinion (Yorkshire Ins. Co. v. Craine, [1922] 2 A.C. 541 (P.C.)) does not bear out its conclusion that under English law defendant had not waived the limitation provision.

Judge Frank's public policy determination is contrary to past cases. See cases cited note 4 supra. Since the Restatement does not recognize the intent of the parties as controlling, see note 1 supra, it is valueless as authority where the issue is one of intent. See cases cited note 14 infra. And since the English conflict of laws rule is to honor the intent of the parties, Vita Food Products, Inc. v. Unus Shipping Co., [1939] A.C. 277 (F.C.), and English courts are prone to find that English law was intended to govern, 2 BEALE, op. cit. supra note 4, at 1102, it is highly doubtful that an English court would apply American law to the issue of waiver. As to the criticism of the majority's interpretation of English law, see note 12 stipra.

14. See Wood \& Selick, Inc. v. Compagnie Generale Transatlantique, 43 F.2d 941 (2d Cir. 1930) ; Dorff v. Taya, 194 App. Div. 278, 185 N.Y. Supp. 174 (1st Dep't 1920); Yntema, "Autonomy" in Choice of Lazu, 1 Arr. J. Conr. L. 341, 353 (1952).

It may be argued that the above cases are not controlling because the procedural matters with which they deal are not contract terms. But since the requisites of waiver (other than authority to waive, see note 8 supra), are also a procedural question and vere not present in the Siegelman ticket, that issue should be determined in accordance with the cases cited above. Moreover, the limitation of actions provision is drafted strictly with reference to American law, see note 7 supra, and it might be incongruous to treat a waivcr of the provision according to foreign law.

15. 3 BeAle, op. cit. supra note 4 , at 1620 . The statute is considered to limit the remedy only. Goodrich, Conflict of Laws 240 (3d ed. 1949) ; Restatement, Conflict of Laws $\$ \S 603-04$ (1934). But if the liability and the limitation are created by the same statute, the limitation is usually said to be a substantive limitation of the right, and the limitation of the forum is not applied. Wilson v. Massengill Co., 124 F.2d 666 (6th Cir.), cert. dinicd, 316 U.S. 686 (1942) ; Calvin v. West Coast Power Co., 44 F. Supp. 783 (D. Ore. 1942) : 3 Beale, op. cit. sitpra, at 1627. Contra, Wells v. Simonds Abrasive Co., 345 U.S. 514 (1953), affirming 195 F.2d 814 (3d Cir. 1952) ; Cauley v. Massengill Co., 35 F. Supp. 371 (D. Tenn. 1940). But foreign statutory limitations are not used unless they spccifically qualify statutory rights. Compare Davis v. Mills, 194 U.S. 451 (1904); Maki v. Gcorge R. Cooke Co., 124 F.2d 663 (6th Cir.), cert. denied, 316 U.S. 686 (1942) (specific qualifications), with Bournias v. Atlantic Maritime Co., 220 F.2d 152 (2d Cir. 1955), 55 Colum. L. Rev. 1072; Thomas Iron Co. v. Ensign-Bickford Co., 131 Conn. 665, 42 A.2d 145 (1945) (qualifications not specific). 
ground that these matters are also procedural. ${ }^{16}$ Moreover, courts, in classifying contractual limitations as either substantive or procedural, make the same sort of analysis which they use in dealing with statutory limitations. ${ }^{17}$ Applying traditional conflicts doctrine to Siegelman, therefore, waiver of the limitation of actions provision in a negligence suit, ${ }^{18}$ where a statute of limitation would be considered procedural, should also have been regarded as procedural and judged by federal law. ${ }^{19}$

16. Contractual: Titus v. Wells Fargo Bank \& Union Trust Co., 134 F.2d 223 (5th Cir. 1943) (validity of contractual waiver of the statute).

Non-contractual: Van Dyke v. Parker, 83 F.2d 35 (9th Cir. 1936) (tolling of statute by letter acknowledging justness of adverse party's claim); Graham v. Englemann, 263 Fed. 166 (S.D. Tex. 1920) (tolling of statute by defendant's absence from jurisdiction); Dunn Constr. Co. v. Bourne, 172 Miss. 620,159 So. 841 (1935) (tolling of statute by suit against another person jointly liable).

17. Substantive: compare Home Ins. Co. v. Dick, 281 U.S. 397 (1929), with Wilson v. Massengill, 124 F.2d 666 (6th Cir.), cert. denied, 316 U.S. 686 (1942).

Procedural: compare Titus v. Wells Fargo Bank \& Union Trust Co., supra note 16, with State Compensations Ins. Fund v. Proctor \& Schwartz, Inc., 102 F. Supp. 451 (E.D. Pa. 1952).

18. Federal courts have never held this type of action to arise ex contractu, Jansson v. Swedish American Line, 185 F.2d 212 (1st Cir. 1950) (maritime tort) ; Rosenthal v. Compagnie Generale Transatlantique, 14 F.R.D. 33 (S.D.N.Y. 1953) (negligence), notwithstanding contrary state decisions involving nonmaritime claims, Dyke v. Erie Ry., 45 N.Y. 113 (1871) ; Strickler v. Palmer, 73 N.Y.S.2d 389, 190 Misc. 688 (Sup. Ct. 1947). The federal position appears more tenable, since the duty to exercise due care extends to nonpaying passengers, Radermacher v. St. Paul City Ry., 214 MIinn. 427, 8 N.W.2d 466 (1943); Parker v. Bissonette, 203 S.C. 155, 26 S.E.2d 497 (1943), although the duty to these passengers may be expressly waived, Kansas City So. Ry. v. Van Zant, 260 U.S. 459 (1923) ; Stevens v. Colombian Mail S.S. Corp., 15 F. Supp. 534 (S.D.N.Y. 1936); Anderson v. Erie R.R., 223 N.Y. 277, 119 N.E. 557 (1918).

Whether a maritime action in a federal court is instituted on grounds of original or diversity jurisdiction, federal maritime law must be applied. Pope \& Talbot, Inc. v. Hawn, 346 U.S. 406 (1953) ; Chelentis v. Luckenbach S.S. Co., 247 U.S. 372 (1918). In Siegelman v. Cunard White Star Ltd., 221 F.2d 189 (2d Cir. 1955), this principle led the court to apply federal rather than state conflict of laws rules. See also Jansson v. Swedish American Line, supra. But where there is no federal law on the issue, a state statute may be applied. Wilburn Boat Co. v. Fireman's Fund Ins. Co., 348 U.S. 310 (1955) ; Comment, $50 \mathrm{Nw}$. U.L. REv. 677 (1955). In a maritime action a state court may not apply its own common law if that conflicts with the federal maritime law. Carlisle Packing Co. v. Sandanger, 259 U.S. 255 (1922); Pope \& Talbot, Inc. v. Hawn, supra at 409-10 (dictum). Fut sec Caldarola v. Eckert, 332 U.S. 155 (1947); Pope \& Talbot, Inc. v. Hawn, supra at 414,418 (concurring opinion). And a state court must apply an applicable federal statute, Garrett v. Moore-MicCormack Co., 317 U.S. 239 (1942), but within a limited area may apply its own statute where that does not conflict with federal law, C. J. Hendry Co. v. Moore, 318 U.S. 133 (1943).

19. Under federal law plaintiff would probably not be barred by the limitation of actions provision. Federal admiralty courts have held that estoppel to plead a contractual limitation is created when the behavior of one party induces the other to refrain from bringing suit. Scheibel v. Agwilines, Inc., 156 F.2d 636 (2d Cir. 1946); Green Star S.S. Co. v. Nanyang Bros. Tobacco Co., 3 F.2d 369 (9th Cir. 1925) ; DeFarconnet v. Western Ins. Co., 110 Fed. 405 (S.D.N.Y. 1901), aff'd, 122 Fed. 448 (2d Cir.), cert. denied, 190 
Nor do the court's reasons for honoring the English law stipulation justify its extension to the issue of waiver. Although in some situations choice of law provisions may eliminate the burden of resolving conflict of laws questions, the provision here necessitated interpretation of English waiver law which was unfamiliar both to the court and to one of the parties. ${ }^{20}$ And while uniformity of results in litigation is desirable to avoid disappointing the expectations of the parties, ${ }^{21}$ application of the ambiguous English law provision in Siegelman frustrated plaintiff's reasonable expectation that the limitations clause had been waived. ${ }^{22}$ Moreover, in future cases American parties concerned with similar questions will be required to govern their conduct by a foreign law.

The Siegelman case raises the broader issue of whether steamship tickets should be treated as ordinary contracts or as contracts of adhesion. The majority opinion, in considering the conflict of laws question, applies standard contract doctrine to the ticket. This contrasts sharply with the dissent which

U.S. 558 (1903). A contractual limitation, once tolled, does not revive. Semmes v. Hartford Fire Ins. Co., S0 U.S. (13 Wall.) 158 (1871) ; Lynchburg Cotton Mill Co. v. Travelers' Ins. Co., 149 Fed. 954 (4th Cir. 1906).

In Siegelman the inference can be drawn from the conversation between defendant's agent and plaintiff's attorney that the inducement to refrain from bringing suit was the chance of a better settlement. Evidently, Cunard desired settlement of the claim to promote good will. Siegelman v. Cunard White Star Ltd., 221 F.2d 189, 197 (2d Cir. 1955).

20. The burden on the court of applying foreign law has usually been considered a factor favoring the use of the lex fori. 3 BEALE, op. cit. supra note 4, at 1599; Ailes, Substance and Procedure in the Confict of Laws, 39 Micr. L. Rev. 392, 417 (1941). See Bournias v. Atlantic Maritime Co., 220 F.2d 152, 156 (2d Cir. 1955), where Judge Harlan declined to apply the Panama statute of limitation partly because of unwillingness to furce American courts to examine "the unfamiliar peculiarities and refinements of different foreign legal systems." Perhaps some distinction may be drawn between civil law and common law countries. See ibid. And undoubtedly the burden on the court in the Siegelnan case was further lightened by its training in English law. See Who's Wro IN Avrerics 1129 (1954-55). But see note 12 supra.

The added burden on the parties' attorneys of proving foreign law has also been uscd to justify the application of the lex fori. Bournias v. Atlantic Miaritime Co., supra at 15t; 3 BEale, op. cit. supra, at 1599; Ailes, supra, at 417. Furthermore, it would scem that where the foreign company is one operating extensively in the United States, the burden on the American party and his attorney is a disproportionate one.

21. Restatement, Conflict of Laws, c. 12 Introductory Note (1934); Goodrich, op. cit. supra note 15, at $8 ; 1$ Rabel, The Conflict of Laws: A Conparatrve Study 87 (1.945) ; see 1 BEALE, op. cit. supra note 4, at 46-47.

22. Since waiver of the clause should have been a procedural matter, plaintiff': attorney could have relied on the fact that the remarks of the Cunard agent constituted waiver under federal law. See notes 14-19 supra and accompanying text. And since the ticket provision limiting the agent's authority to waive was concerned only with the alteration of substantive rights, see note 8 supra, it should not have restricted his authority with regard to this procedural matter.

It could also be argued that waiver is equivalent to a new contract, and therefore, that the English law clause relating to matters arising "on the contract," see note 9 supra, was inapplicable. But as with the procedural-substantive distinction, whether English law applies would depend on the intent of the contracting parties. See cases cited note 14 supra. 
views such tickets as adhesion contracts and therefore subject to special treatment. ${ }^{23}$ Adhesion contracts are agreements in which one party, in order to contract with another, must accept a formalized document prepared by the other. ${ }^{24}$ Several significant characteristics are often associated with these contracts : provisions may be one-sided because drafting is done solely by the stronger party $;^{25}$ the terms are typically in technical language and small print ${ }^{26}$ and are not read by the adherer ; 27 any detailed "intent" ascribed to him is generally fictional ${ }^{28}$ and he usually has no opportunity to obtain different conditions by contracting elsewhere. ${ }^{29}$ Numerous authorities have emphasized these characteristics in concluding that all adhesion contracts require distinctive treatment. ${ }^{30}$ Some have urged that standard contract doctrine, based as it is on the "intent of the parties," is wholly irrelevant. ${ }^{31}$

The factors generally associated with adhesion contracts are often found in steamship tickets, and some courts seem to have been influenced by these factors in circumventing ticket provisions to benefit passenger-adherers..$^{32}$ But the courts have been inconsistent in their use of such special treatment ${ }^{33}$ and have failed

23. Siegelman v. Cunard White Star Ltd., 221 F.2d 189, 204 (2d Cir. 1955).

24. Patterson, The Delivery of a Life Insurance Policy, 33 Harv. L. Rev. 198, 222 (1919). Other commentators have incorporated additional elements into their definition of adhesion contracts. See Kessler, Contracts of Adhesion-Some Thoughts About Freedom of Contract, 43 CoLvar. L. Rev. 629, 632 (1943); Sales, Standard Form Contracts, 16 Moderis L. Rev. 318, 319 (1953). For ease of analysis Patterson's earlier definition is here adopted and these additional elements and other characteristics are reserved for separate discussion. See text at notes 34-48 infra.

25. Llewellyn, What Price Contract?-An Essay in Perspective, 40 Yale L.J. 704, $731-37$ (1931); Sales, supra note 24, at 321-23; Note, 63 Harv. L. Rev. 494 (1950); see Cohen, The Basis of Contract, 46 Harv. L. Rev. 553, $587-89$ (1933).

26. Mellinkoff, How to liake Contracts Illegible, 5 Stan. L. Rev. 418 (1953); Note, 13 Harv. L. Rev. 494 (1950).

27. Note, 210 L.T. 351 (1950) ; Llewellyn, Book Review, 52 Harv. L. Rev. 700, 704 (1939). See also authorities cited note 26 supra.

28. See Jansson v. Swedish American Lines, 185 F.2d 212, 219 (1st Cir. 1950) ; Kessler, supra note 24, at 632; Sales, supra note 24 , at 318 ; cf. Wright, Opposition of the Laze to Business Usages, 26 Colum. L. Rev. 917, 930 (1926).

29. Kessler, supra note 24 , at 632 ; Wright, supra note 28 , at 930 ; Note, 58 YaLE L.J. 1161,1162 (1949).

30. See Bekken v. Equitable Life Assurance Soc'y, 70 N.D. 122, 143, 293 N.W. 200, 212 (1940) ; Kessler, supra note 24, at 640-42; Sales, supra note 24, at 337-42; Llewellyn, Book Review, 52 Harv. L. Rev. 700, 704 (1939).

31. Sugar v. London Midland \& Scottish Ry. Co., [1941] 1 All E.R. 172 (K.B. 1940) ; Kessier, suipra note 24 , at 636 .

32. Burstein v. United States Lines, Co., 134 F.2d 89 (2d Cir. 1943) ("claim for bodily injury" in 49 Stax. 960, (1935), 46 U.S.C. $\$ 183$ (b) (1952) held to include medical exrunses and loss of services, thereby invalidating six months limitation provision); Scire v. American Export Line, Inc., 197 Misc. 422, 93 N.Y.S.2d 457 (Sup. Ct. 1949) (invalid hlanket exculpation clause in baggage receipt held to void valid provision in ticket issued earlier).

33. In Baron v. Compagnie Generale Transatlantique, 108 F.2d 21 (2d Cir. 1939), a provision requiring that written notice of a claim be given to the purser before debarkation or to the carrier within fifteen days of injury was held to bar the passenger's action. The 
to formulate express rules for its application. ${ }^{34}$

The single circumstance that a passenger must "take-or-leave" the formalized document of a company seems insufficient to justify affording him a preferred status. But unique treatment is necessary to avoid oppressive consequences resulting from particular characteristics of steamship ticket transactions.

Ticket drafting by steamship companies, whose bargaining ability greatly exceeds that of passengers, may lead to provisions which are unfair, ${ }^{35}$ even if not contrary to public policy, and when this occurs, courts should use the equitable doctrine of unconscionable bargain to avoid harsh results. To a greater extent than the public policy restriction, the unconscionable bargain doctrine allows courts, in determining the enforceability of contract provisions, to consider the circumstances existing at the time of the making of a contract.98

court was unimpressed by the fact that the passenger had spoken to the purser about her injury, that the purser had told her she need not further notify the company and had taken notes of her report, and that the passenger had written a letter one day after debarkation cancelling the return voyage because of her injury. And in Secoulsky v. Oceanic Steam Nav. Co., 223 Mass. 465, 112 N.E. 151 (1915), the passenger was held to a $\$ 50$ limitation of liability provision, even though he could not read or write English and, upon asking the company's ticket agent whether he should insure, was informed that insurance was unnecessary. See also Murray v. Cunard S.S. Co., 235 N.Y. 162, 139 N.E. 226 (1923) ; Rosenthal v. Compagnie Generale Transatlantique, 170 Misc. 426, 12 N.Y.S.2d 102 (Sup. Ct. 1939).

For a striking contrast in approach in a single case, compare the majority and dissenting opinions in Reichmann v. Compagnie Generale Transatlantique, 290 N.Y. 344, 352, 49 N.E.2d 474, 477 (1943).

34. Whether or not courts give special treatment to these tickets, they generally fail to verbalize any distinction between them and standard contracts. See cases cited in notes 32-33 supra. The circuitous methods used by the courts in dealing with adhesion contracts in general have been variously characterized as "interpretation," 1 ConBIN, ConTRICTs $\$$ 128 (1950), "recovery by the back door," Kessler, supra note 24, at 635, and "semi-covert techniques," Llewellyn, Book Review, 52 HARv. L. REv. 700, 702 (1939). For a novel approach wherein the court ignored a limitation of liability provision, see Klar v. H. \& M. Parcel Room, Inc., 296 N.Y. 1044, 73 N.E.2d 912 (1947). All these methods have been criticized as an ineffective long range solution. Kessler, stpra, at 633; Llewellyn, supra, at 703; Note, 58 Yale L.J. 1161, 1170-71 (1949).

35. An example of such a provision is one which, after partially exculpating the carrier from liability for damage to baggage, provides the passenger with an option to insure the excess baggage at the rate of $5 \%$ of its value. Such a provision does not contravene public policy. See Goddard, Contract Limitations of the Common Carrier's Liahility, 8 Micr. L. REv. 531, 544 (1910). At the present time, however, most steamship companies charge only $1 \%$ for such excess baggage, but at least one charges $5 \%$. See Letters from steamship companies to Yale Law Journal, Dec. 2-22, 1955, on file in Yale Law Library.

For provisions which are against public policy, see The Kensington, 183 U.S. 263 (1902) ; Oceanic Steam Nav. Co. v. Corcoran, 9 F.2d 724 (2d Cir. 1925) ; Barndt v. Det Bergenske Dampskibsselskab, 28 F. Supp. 815 (S.D.N.Y. 1938).

36. See Uniforar Conimercial Code $\$ 2-302$ \& comment; 1 Corbin, Contracts $\$ 128$ (1950) ; Note, 63 YALE L.J. 560 (1954).

Another disadvantage of the public policy doctrine is that courts are often reluctant to extend it to new areas. J. Stone, The Province and Function of Law 494-504 (1946). 
Application of this doctrine, already extensively used by courts of admiralty, ${ }^{37}$ would permit evaluation of such factors as a passenger's inability to comprehend oppressive consequences of involved provisions or the unavailability elsewhere of different terms even where such consequences are clear from the ticket itself.

An important consideration in deciding whether to hold passengers to the terms of steamship tickets which are not unconscionable is the fact that many passengers do not read their tickets. ${ }^{38}$ Some federal courts have held that before a passenger will be bound by a provision the company must not only incorporate the term into the ticket by reference, but must also give the passenger notice of it. ${ }^{39}$ Siegelman, however, apparently follows the more prevalent rule that sufficient incorporation alone will make provisions binding. ${ }^{40}$ Incorporation probably affords a passenger sufficient notice where knowledge of a provision, such as the limitation of actions clause in the Siegelman contract, would probably not influence his acceptance of a ticket or his behavior prior

37. Many admiralty decisions have applied an unconscionable bargain rationale to invalidate salvage contracts whose unfair terms were traceable to the parties' manifestly unequal bargaining power. E.g., Magnolia Petroleum Co. v. National Oil Transp. Co., 281 Fed. 336 (S.D. Tex. 1922), modified, 286 Fed. 40 (5th Cir. 1923); Spreckels v. The Don Carlos, 47 Fed. 746 (N.D. Cal. 1891); The Young America, 20 Fed. 926 (D.N.J. 1884).

38. See, e.g., Oceanic Steam Nav. Co. v. Corcoran, 9 F.2d 724 (2d Cir. 1925) ; Rogers v. Furness, Withy \& Co., 103 F. Supp. 314 (W.D.N.Y. 1951).

Failure to read a contract is ordinarily no defense unless there is misrepresentation. 3 Corsin, Contracts $\$ 607$ (1950); Note, 28 Notre Dame Law. 136 (1952). But the undesirability of this rule as applied to the standard contract form has been recognized. See Mellinkoff, supra note 26 , at 432 (suggesting a rebuttable presumption of nonreading where the type is below a certain size); Sales, supra note 24, at 337-42 (advocating legislative preparation of all standard form contracts to protect the nonreading adherer) ; Note, 210 L.T. 351 (1950) (raising the question whether terms in the "standard form" contract not previously discussed by the parties should be stricken out). Many states have statutes regulating the type-size of insurance contracts. E.g., N.Y. INs. LAW $\$ 164(2)$.

39. Azrak v. Panama Canal Co., 117 F. Supp. 334 (S.D.N.Y. 1953); see The Kungsholm, 86 F.2d 703 (2d Cir. 1936); cf. Foster v. Cunard White Star, Ltd., 121 F.2d 12 (2d Cir. 1941).

40. Isthmian S.S. Co. v. MfcElligott, 177 F.2d 591 (5th Cir. 1949); Jansson v. Swedish American Line, \$9 F. Supp. 557 (D. Mass.), rev'd on other grounds, 185 F.2d 212 (1st Cir. 1950); Cohn v. United States Lines Co., 84 F. Supp. 503 (D.N.J. 1949).

The court in Siegelman held only that these tickets are contracts and that their provisions are binding. Siegelman v. Cunard White Star Ltd., 221 F.2d 189, 193 (2d Cir. 1955). The absence of a discussion of notice appears to indicate that the court considered proof of notice irrelevant.

New York state courts have consistently held that tickets are contracts and that notice is irrelevant. E.g., Murray v. Cunard S.S. Co., 235 N.Y. 162, 139 N.E. 226 (1923) ; Rasmussen v. Gdynia America Lines, Ltd., 126 N.Y.S.2d 872 (Sup. Ct. 1953). And some federal courts have relied on these state decisions in holding notice irrelevant. Horvath v. Cunard S.S. Co., 103 F. Supp. 356 (E.D.N.Y. 1953) ; Rogers v. Furness, Withy \& Co., 103 F. Supp. 314 (W.D.N.Y. 1951) (dictum). However, in admiralty only the general body of maritime law as enunciated by federal courts is controlling. See note 18 supra. 
to contemplation of litigation. ${ }^{41}$ But where knowledge of a clause, such as a warning to insure baggage, ${ }^{42}$ might affect a passenger's conduct prior to seeking legal advice, a showing that he had the opportunity to read his ticket should be necessary to hold him to the term. The opportunity to read, however, is ineffectual if reading a provision is an unreasonable burden because it is contained in small print or is spaced closely. Since notice is imputed to a person only because he should have discovered information through reasonable diligence, ${ }^{43}$ the reasonableness under the circumstances of requiring that a ticket provision be read should be an additional issue. ${ }^{44}$

The basic fallacy involved in applying standard contract doctrine to steamship tickets is that the "intent of the parties"-the purported basis for enforcement of consensual agreements - is usually nonexistent. A passenger seeling terms different from those offered by the company may not be able to obtain

41. It is difficult to imagine that either the one year limitation provision, see note 7 supra, or the choice of law provision, see note 9 supra, would have influenced plaintiff's desire to book passage aboard the Queen Elizabeth or altered his subsequent behavior prior to consulting his attorney. Where a ticket provision is of this nature, the only notice needed is to the passenger's attorney that the provision is part of a contract. And sufficient incorporation affords this notice. However, since contract is a consensual arrangement, a showing by a passenger that knowledge of any provision would have influenced his behavior should free him from its effects if he had no notice of it.

42. See provision 6 of the Cunard ticket reprinted in Siegelman v. Cunard White Star Ltd., 221 F.2d 189, 208 (2d Cir. 1955). Also in this category are provisions requiring notice of the passenger's claim within a short period of time and provisions limiting the authority of the carrier's agents. See provisions $10(\mathrm{a})$ and 11 of the Cunard ticket reprinted in $i d$. at 209 . These or similar provisions appear in substantially all steamship tickets. See note 45 infra.

Another feature peculiar to steamship ticket transactions is that passengers are often required to surrender their contracts before their voyage begins. See, e.g., Rogers v. Furness, Withy \& Co., 103 F. Supp. 314 (W.D.N.Y. 1951) ; Murray v. Cunard S.S. Co., 235 N.Y. 162, 139 N.E. 226 (1923). Consequently, where knowledge of a provision is necessary after that time, earlier notice of that provision is ineffective unless it has been memorized by the passenger. In such a situation, giving the passenger the ticket originally should not be considered notice.

43. 1 Merrill, Notice $\$ 70$ (1952). The rationale for holding the nonreader to the terms of the contract is either that "he is estopped by his 'negligence,' or that he must suffer the consequences of his "folly'...." 3 Corbin, Contracts $\$ 607$ (1950).

44. There are accurate standards for determining "constructive illegibility." Psychological reading studies show that for ordinary reading material eleven-point type is the most desirable; type under nine-point is unsatisfactory; and type under six-point is illegible from the standpoint of ordinary ease of reading. Mellinkoff, supra note 26, at 419. The text of this Note is printed in ten-point type, the footnotes in eight-point. Steamship ticket provisions range from five-point to eight-point type. See Letters from steamship companies to the Yale Law Joumal, Dec. 2-22, 1955, on file in Yale Law Library. It is suggested that if a provision is one which should be brought to the attention of passengers, see text at note 42 supra, there should be a rebuttable presumption of nonreading where type is under ninepoint. See Mellinkoff, supra note 26 , at 432 . And where the type size is greater than ninepoint, unreasonable crowding should create the same rebuttable presumption. For an example of close spacing, see the Cunard ticket reprinted in Siegelman v. Cunard White Star Ltd., 221 F.2d 189, 208-09 (2d Cir. 1955). 
them by bargaining or by contracting elsewhere. ${ }^{45}$ At other times his inexpertness may prevent him from comprehending the significance of his agreement. In both cases a passenger's acceptance of a ticket clause may be a submission to the will of the company rather than an expression of his intent.46 A good example of this is Siegelman, for it is most unlikely that when the passenger bought his ticket he had any intention concerning application of English law to the question of waiver.

The relevant intention of the parties is that indicated by their subsequent behavior, not a standardized, fictional intent inferred from mere acceptance of a document. Only during negotiations which follow a dispute does a passenger have the opportunity to seek a variation of the standard contract. And only at that time does mutuality of intent enter the contractual relationship. Therefore, where subsequent behavior inconsistent with a ticket provision demonstrates an intention by the parties to create a new agreement, tailored to meet the needs of the individual situation, the company should not be allowed to rely on an earlier ticket provision. ${ }^{47}$ In Siegelman, for example, the court should have determined the law applicable to the issue of waiver by examining the parties' behavior during negotiations. Such an approach would have led to the application of American law, since the passenger's attorney intended American law to govern, and Cunard acquiesced in this view. ${ }^{48}$

45. It seems apparent that it does not occur to most passengers to bargain about any terms of the contract other than price and accommodations. However, an attempt to bargain would in any event probably be unsuccessful. Most transatlantic steamship tickets contain substantially the same provisions. The minimum notice requirement of six months and limitation of actions period of one year, established by 49 STAT. 960 (1935), 46 U.S.C. $\$ 183$ (b) (1952) for causes of action regulated by this section, are in all tickets. For causes of action not regulated by $\$ 183$ (b) the limitation period varies from four to six months and the notice requirement from fifteen days to two months. All companies strictly define requisites for waiver of contract provisions. Requirements range from no waiver possible by any subsequent action of company employees to waiver possible only in writing by a specific agent of the company. The limitation of liability for damage to baggage is ubiquitous, the amount varying from $\$ 50$ to $\$ 250$, and the rate of insurance for excess baggage varying from $1 \%$ to $5 \%$ of its value. See Letters from steamship companies to Yale Law Journal, Dec. 2-22, 1955, on file in Yale Law Library. The passenger does, however, have his choice of law, for most companies prefer to stipulate no law or to apply their own law to questions arising on their contracts. Ibid.

A similar disparity in bargaining ability exists where, although other companies do provide different terms, market conditions make it impossible for a passenger to book passage elsewhere.

46. See authorities cited note 28 supra.

47. By provisions which limit the possiblity of waiver steamship companies have attempted to preclude such holdings. See note 45 supra. And they have usually been successful. See Scheibel v. Agwilines, Inc., 156 F.2d 636 (2d Cir. 1946) ; Baron v. Compagnie Generale Transatlantique, 108 F.2d 21 (2d Cir. 1939); Eichler v. Furness, Withy \& Co., 169 Misc. 22, 6 N.Y.S.2d 893 (N.Y. City Ct. 1938). But the Siegelman case indicates that courts may be beginning to use the doctrine of apparent authority to find waiver from the conduct of company agents. Siegelman v. Cunard White Star Ltd., 221 F.2d 189, 197-98 (2d Cir. 1955).

48. Cunard's express revocation of its offer after expiration of the limitation period implies that it considered its agent's prior actions to constitute waiver. The fact that Cunard 
The suggestion of the dissent that steamship tickets be treated specially should not be ignored. When those characteristics of adhesion contracts which cause injustice are present in steamship ticket transactions, the application of standard contract doctrine is unsuitable. Instead courts should apply distinctive treatment designed to strike at the cause of particular oppressive traits. But without these qualities the "take it or leave it" nature of the transaction does not justify judicial abandonment of conventional contract law.

did not plead English law when the action was before the district court, see note 10 supra. supports the further inference that at the time of negotiations it did not consider its agent's behavior governed by English law. 